\title{
Goal orientation and mastery climate: a review of contemporary research and insights to intervention
}

\author{
Orientação de metas e contexto para a maestria: \\ uma revisão de pesquisas contemporâneas \\ e considerações para intervenções
}

\author{
Nadia Cristina VALENTINI \\ Mary Elizabeth RUDISILL ${ }^{2}$
}

\begin{abstract}
This manuscript is a review of human achievement motivational theory, that emphases goal orientation and mastery climates. Specifically, it provides an overview of goal orientation researches and discusses how much the implementation of motivational climates in learning settings affects children and adolescents' psychological and behavioral responses. The manuscript concludes with further discussion about researches in this field, and emphases the in learning environments practical application.
\end{abstract}

Key words: goal orientation; achievement motivation; mastery learning.

\section{Resumo}

Este artigo é uma revisão da teoria motivacional de conquistas, com ênfase na orientação de metas e contextos motivacionais para a maestria. Especificamente, o artigo propicia uma visão geral de pesquisas conduzidas em orientação de metas e discute como a implementação de contextos de motivação na aprendizagem influencia respostas psicológicas e comportamentais de crianças e adolescentes. O artigo conclui com uma discussão crítica sobre linhas de pesquisas futuras nesta área, enfatizando a aplicação prática em contextos de aprendizagem.

Palavras-chave: orientação de metas; motivação para conquistas; contexto para maestria.

The motivation conception has played an important and distinguished role in the studying of educational environment over the last decade. Researchers have studied educational motivation in laboratories as well as in real-world settings (Ames, 1992a, 1992b; Brophy, 1983; Burhands \& Dweck, 1995; Maehr, 1984; Meece \& Holt, 1993; Nicholls, 1984, 1992a, 1992b).
The goal-oriented perspective has been one of the most recent education subjects motivational research. This perspective provides an explanation for the approaches, responses, and reasons that individuals use to engage in achievement activities (Ames, 1992a). It is suggested that two qualitatively different motivational constructs emerge when the individual engages in achievement

1 Professora Doutora, Escola de Educação Física, Universidade Federal do Rio Grande do Sul. Rua Felizardo, 750, Jardim Botânico, 90690-200, Porto Alegre, RS, Brasil. Correspondence to/Correspondência para: N.C. VALENTINI. E-mail: <nadiacv@esef.ufrgs.br>.

2 Phd, Course Health and Human Performance, Auburn University. Auburn, AL, USA. 
activities. These concepts have been labeled as mastery and performance goal orientation. The strongest component of a mastery goal is the belief that effort and outcome are correlated; whereas, in a performance goal orientation, the belief is that the individual's perception of ability and sense of self-worth, doing better than others, are more important (Ames, 1992a, 1992b; Nicholls, 1984).

In addition, it has been theorized that when learners face difficulty and failure, they can adopt, depending on their own goal orientation - mastery or performance - two distinct motivational patterns. These include an adaptive or a non-adaptive motivation patterns ( Ames, 1992b; Dweck, 1986; Dweck \& Leggett, 1988; Meece, Blumenfeld, \& Hoyle, 1988; Nicholls, 1984). Mastery-oriented individuals seem to adopt an adaptive motivation pattern, which leads to a challenge-seeking attitude. Performance-oriented individuals seem to adopt a non-adaptive motivation pattern, which leads to avoidance of challenge and helpless attitudes.

The goal-oriented perspective has been investigated in a variety of achievement settings, including classrooms (Ames \& Archer, 1988; Ames, 1992a, 1992b; Burhands \& Dweck, 1995; Maehr 1984; Meece \& Holt, 1993), adult and youth sports, and motor learning settings (Duda, 1992; Robert, 1992; Rudisill, 1991; Seifriz, Duda \& Chi, 1992; Walling, Duda, \& Chi, 1993). In these studies, researchers have been interested in determining how influent the goal orientation approach was to intrinsic motivation (Meece et al., 1988; Meece \& Holt, 1993), perceived competence (Rudisill, Mahar \& Meaney, 1993) and motor skill development (Martin, 2001; Rudisill, 1989; Theeboom, Knop \&Weiss, 1995; Valentini \& Rudisill, 2004a, 2004b). In general, these studies have shown that (1) individuals adopted different patterns of goal orientation when in achievement settings; (2) these patterns adoption had consequences on the individual's motivation toward the learning process; and that (3) changes in perceived competence, social acceptance, intrinsic motivation, persistence, and motor development are observed as a result of the patterns adopted.

There is also evidence that suggests intervention programs designed to increase the frequency and quality of children's mastery-oriented experiences will result in high achievement motivation, especially for those who are low achieving or at risk of school failure (Newsham, 1989; Valentini, 2002a, 2002b; Valentini \& Rudisill, 2004a, 2004b; Weigand \& Burton, 2002). This research has supported the mastery climate created by the teacher affects the learning process, fostering achievement and motivation among children and adolescents (Ames, 1992a, 1992b; Epstein, 1988, 1989; Valentini, 2002a, 2002b; Valentini \& Rudisill, 2004a, 2004b).

The following review provides a discussion about important constructs associated to children's motivation and achievement in educational settings. First, there is a brief review of the goal orientation perspective, which is the theoretical framework of a mastery climate. Second, it is presented a discussion about mastery climate and its influence on learning process. Third, there are considerations about practical implications.

\section{Goal orientation perspective}

Drown from the social cognitive approach, the goal orientation perspective has been used to explain achievement behaviors in a variety of learning environments. Specifically, this approach reveals why people approach, engage in, and respond to achievement activities, as well as they engage in certain achievement behaviors (Ames, 1992a).

Two distinct constructs of achievement goals have been concerned: mastery and performance (Ames, 1987; Ames \& Archer, 1988). It has been suggested that mastery and performance concepts had been originated from two qualitatively opposite motivational frameworks. These constructs have also been referred as goals of learning and performance (Dweck, 1984), task and ability (Maehr \& Midgley, 1991), or task and ego involvement (Nicholls, 1984, 1992b). The terms mastery and performance goals were used in this manuscript according to the clarity and consistency purpose. Mastery and performance constructs can be differed according to the way learning, effort, and success are perceived and valued; the approaching and engaging reasons for the achievement activity; and the individual's thoughts, tasks, and outcomes (Ames, 1992b; Meece et al., 1988; Nicholls, 1984).

Mastery-oriented individuals seem to place a relevant role to the learning process, and learning is an 
end itself. Motivation to learn is intrinsically attributed (Ames, 1992a; Nicholls, 1984). The essential of mastery goal orientation is the belief that effort and outcomes are correlated. In other words, effort leads personal progress and mastery (i. e., more effort means more ability). This belief helps the individual to build a pattern of achievement behaviors that has long-term implications for learning (Ames, 1992a). Mastery goal oriented individuals seek new skills, improve personal competence, or attain a sense of mastery based on their set of standards (Ames, 1992b). Therefore, they select tasks that challenge their ability and enhance their competence (Maehr, 1983).

Performance-oriented individuals realize learning as a way to demonstrate superior capacity, that is extrinsically attributed. The individual's ability and a sense of self-worth are the performance goal orientation focus. Ability is when a person does something better than the others (i. e., surpassing normative-based standards) and/or gets successes with little effort (Ames, 1992b). Individuals oriented toward performance goals are motivated to seek public recognition (Nicholls, 1984); to obtain positive and avoid negative judgments about their performance (Dweck, 1986); and to compare their own performance and effort with others. They do not attempt to learn if it appears unlikely to enable them to demonstrate high capacity (Nicholls, 1984). They think the harder they try, the less ability they have. This belief might lead the person to avoid effort in order to protect his/her ability and self-worth (Covington, 1984). Consequently, different motivational patterns seem to emerge as an outcome of the individual's orientation toward mastery or performance goals, especially when facing difficult tasks (Ames, 1992b; Ames \& Archer, 1988; Dweck, 1986; Dweck \& Leggett, 1988; Nicholls, 1992a, 1992b). The adoption of a mastery goal is similar lead the individual to an adaptive motivational pattern of achievement behavior, whereas the performance goal adoption leads to non-adaptive, helpless motivational patterns of achievement behavior. An adaptive motivational pattern is observed among individuals who are performance goal oriented, as long as their perceived abilities are high (Seifriz, Duda \& Chi, 1992), whereas an adaptive motivational pattern is observed among the mastery goal oriented individuals, regardless of their levels of competence (Ames, 1992b; Covington, 1984; Nicholls, 1984).
A similar motivational pattern is observed in children, from early childhood to adolescence. Children who display the adaptive pattern of motivation focus on strategies when they face failure and have high expectations about future performance. Their persistence is maintained and often increases. In addition, they adopt a challenge-seeking attitude. In other words, they are willing to be challenged in future learning tasks (Dweck \& Leggett, 1988). As a result, the learner interprets failure as a feedback that guides him or her to learn and master other skills.

In contrast, children displaying non-adaptive pattern quickly indicate their ability when encountering failure; also they show negative expectations about future performance and their persistence and performance decrease. They tend to avoid future challenges and attempt to be withdrawn from achievement situations (Burhands \& Dweck, 1995). It seems that the adoption of performance goals creates a framework in which the negative outcomes are interpreted and reflected in the individual's competence. When the child encounters failure, it is attributed to a lack of ability. The child becomes vulnerable to the aspects of helpless patterns; which leads them to a challenge avoidance and performance deterioration, when facing obstacles. Studies demonstrate that even young children are relatively vulnerable to helplessness in some situations (Burhands \& Dweck, 1995; Elliott \& Dweck, 1988; Smiley \& Dweck, 1994). Even before young children have a mature concept of ability, they can engage in global self-blame reaction-response to failure or criticism - the key feature of helpless patterns.

Several studies conducted in the learning environment suggest that a range of outcomes is associated to the adoption of mastery goals, such as: (1) strong correlation between effort and success (Ames \& Archer, 1988; Biddle, Wang, Kavussanu \& Spray, 2001); (2) persistence in learning tasks (Butler 1987; Wolters, 2004); (3) increases in quality of work when facing failure (Dweck \& Leggett, 1988); (4) frequent use of metacognitive and self-regulatory strategies in the learning process (Brookhart \& Durkin, 2003; Meece et al., 1988; Wolters, 2004); (5) high level of active engagement in the activities (Meece \& Holt, 1993) and mental effort (Brookhart, 2003); (6) development of new skills, self-esteem, and perceived competence (Biddle et al., 2001); (7) belief that the purpose 
of practice is fostering mastery (Biddle et al., 2001); (8) low rate of work avoidance (Covington, 1984; Meece et al., 1988; Miller, 1986; Stipek \& Kowalski, 1989) and procrastination (Wolters, 2004); (9) higher levels of sportspersonship (Stornes \& Ommundsen, 2004); and (10) perception of physical education as important, interesting, and useful (Xiang, McBride \& Guan, 2004).

On the other hand, several studies support the contention that the adoption of performance orientation leads students to (1) withdraw themselves from difficult tasks (Ames \& Archer, 1988; Butler 1987); (2) complete the work with effortless, in part to avoid negative judgments of ability, specially when poor performance is expected (Covington, 1984); (3) seek social recognition (Biddle et al., 2001); (4) show superficial levels of engagement (Meece \& Holt, 1993); (5) demonstrate unsporting behavior and less respect for social conventions, opponents, rules, and officials (Biddle et al., 2001; Stornes \& Ommundsen, 2004); (6) believe the practice purpose is achieving social status (Biddle et al., 2001); (7) report more negative than positive emotions (Nichols, Jones \& Hancock, 2003); (8) believe that possessing ability produces success (Biddle et al., 2001). These results seem to be favorable toward the environment where the predominant orientation is focused on mastery goals; therefore, educational research where mastery climate has been implemented in classroom will be discussed next.

\section{Mastery Climate}

A motivational climate is established when the teacher structures the classroom to convey certain goals, cues, rewards, and expectations that are salient in learning environment (Ames, 1992a). Based on the goal orientation research findings, studies have also

$\underset{n}{z}$ investigated the extent, that the different motivational

$\$$ climate participation - performance or mastery - is

influential in personal changing goal orientation and motivational patterns. In fact, cognitive engagement, positive attitude toward learning, and academic behaviors have been the focus of a variety of studies. For example, Ames (1984a, 1984b), and Ames and Archer (1988) reported that children performing in a mastery climate have demonstrated more effort-related cognition and used effective learning strategies, self instruction, and self monitoring types of thoughts more often than children performing in a performance climate.

Depending on the motivational climate, qualitatively different motivational patterns are adopted. Mastery climate leads to (1) a positive attitude toward learning, effort (Ames, 1992b; Corno \& Rohrkemper, 1985; Nicholls, 1989), exercise, and sports (Christodoulidis, Papaioannou \& Digelidis, 2001); (2) the belief that effort and ability cause success and feelings of satisfaction (Treasure, 1997; Treasure \& Roberts, 2001); (3) the belief that success is achieved through intrinsic interest, effort, and cooperation (Walling \& Duda, 1995); (4) focus on effort (Walling \& Duda, 1995) and maintain effort during classes (Christodoulidis et al., 2001); (5) the frequently use self planning to maintain or improve performance (Walling et al., 1993). On the other hand, students who are climate-oriented performance (1) focus on ability as a cause of success (Walling, et al., 1993); (2) report a negative attitude toward the class, boredom, and performance and dissatisfaction worries (Walling et al., 1993); (3) believe that success is achieved when students have high ability (Treasure, 1997).

It seems that, when adequacy of one's ability and public evaluation are emphasized - feature of the performance climate - the students reported effort-minimizing strategies use, such as seeking frequent help, copying answers, and/or guessing solutions (Meece et al., 1988). Interestingly, children who tended to underestimate effort during learning situations were observed using effective learning strategies, when they were told to focus on the task rather than on performance outcomes (Stipek \& Kowalski, 1989). Similar trends are reported with young adults (Gano-Overway \& Ewing, 2004) who have shown low performance-orientation scores, as they perceived the climate oriented toward mastery.

Furthermore, Papaioannou (1995) showed the teachers' attention toward high ability students indicates a performance climate. On the contrary, when students recognized mastery climate, they realized their teachers' positive behavior toward low achievers (Papaioannou, 1995) and the implementation of effective instructional strategies, such as establishing personal goals. The students had also demonstrated self-motivation practice, and incorporation of teachers' feedbackinto their practice (Gano-Overway \& Ewing, 2004). Therefore, teachers might 
develop all students abilities and eliminate the effects of their own negative expectation while stressing the value of personal progress.

Children and adolescents' perceptions about mastery climate were also positively related to autonomy, competence, relatedness (Standage, Duda \& Ntoumanis, 2003); enjoyment, perceived competence (Dunn, 2000), intrinsic motivation (Seifriz et al., 1992), beliefs that effort results in success (Dunn, 2000; Seifriz et al., 1992; Treasure \& Roberts, 2001); greater satisfaction, and lower levels of performance worry (Walling et al., 1993). Furthermore, as shown by Xiang, Lee and Bennett (2002), perceived mastery motivational climate is related to students' self-reported mastery behaviors such as: to focus on effort, strive for mastery, seek challenging tasks, and persist in the face of difficulty. Children report the same trend. Children from a mastery climate had higher expectations, persisted longer in the tasks (Rudisill, 1991), showed motor performance increase (Valentini, 2002a, 2002b; Valentini \& Rudisill, 2004a, 2004b), intrinsic motivation (Valentini, 1997), and perceptions of competence (Valentini, 1997, 2002b; Valentini \& Rudisill, 2004a, 2004b).

In conclusion, the consistent pattern of findings that emerge from the studies previously mentioned supports a mastery climate is beneficial to the learning process. Among the studies attempting to a mastery climate implementation on learning environment, several of them have followed the TARGET (tasks, authority, recognition, grouping, evaluation, and time) strategies and principles proposed by Epstein $(1988,1989)$ and Ames (1992b). Considering the importance of this approach for the implementation of mastery climate, a brief review follows.

\section{Mastery climate and TARGET Interventions}

Ames $(1992 b)$ and Epstein $(1988,1989)$ examined and described classroom structures in terms of how they influence students' motivation and goal orientation. The authors suggested that exemplary mastery practices could be integrated into classroom daily routine, influencing children's mastery motivation over the long term, based on six dimensions of the classroom structure, known as TARGET. Valentini \& Rudisill (2004a, 2004b) and Valentini, Rudisill and Goodway (1999a, 1999b) have adapted the TARGET structure for early interventions to attend young children who demonstrated motor delays or were at risk of school failure. Following there is a TARGET dimensions briefing.

Task: the task structure includes the content and sequence of the curriculum, design of the classroom work and homework, difficulty of the tasks, and the material required to finish the assignments (Epstein, 1988, 1989). Interest in learning associated with a mastery orientation usually occurs when the tasks involve variety, novelty, diversity, discovery or problem solving, challenge that fit the individual needs, and short-term and realistic goals (Ames, 1992b). Also, students appreciate to approach and engage in consistently learning when they perceive meaningful reasons to do so. When valuable activities are presented, students focus on the activity in order to develop and understand its contents, so they can improve and get new skills.

Children's natural tendency to seek competence is observed when tasks are moderately challenging, attainable, and intrinsically motivated (Nicholls, 1989). Optimized challenging tasks in the classroom appear to foster the students' cognitive engagement (Corno \& Rohrkemper, 1985); get the activity involvement (Csikszentmihalyi, 1975); and to nourish intrinsic motivation (Lepper \& Hodell, 1989). Therefore, challenge and novelty are naturally attractive and inherent factors of motivation (Maehr, 1984). However it is important to observe that teachers must structure tasks that provide challenge to fast and slow-learning students in order to foster mastery goals in all of them (Raffini, 1993). The teacher must know students' skill levels and prior knowledge to create challenging tasks that are neither too easy nor too difficult for the students.

All these features of the task structure helps to achieve the desirable mastery climate in the classroom. The inclusion of these factors should result in the adoption of a mastery goal orientation, which enhances motivation.

Authority: the classroom authority structure influences the nature of decision making between teachers and students (Epstein, 1988). In some classrooms, teachers and students share responsibilities of making choices, giving directions, monitoring work, setting and reinforcing rules, providing rewards, and evaluating success. Involving children in decision 
making and supporting their autonomy seems to lead to an adaptive motivational pattern, intrinsic motivation toward learning (Lepper \& Hodell, 1989), and the use of effective learning strategies (Ames, 1992b).

In addition, allowing students to pace their learning process, establish priorities, and develop selfmanagement and self-regulatory strategies, is to foster students' responsibility. This shift of responsibility focus from the teacher to the student is an effective way to administrate ability level difference in the class. So the student's outcomes vary according to their own responses, once they are empowered and hence motivated (Lepper \& Hodell, 1989). On the other hand, if the students' sense of control undermine, there will have detrimental effects on subsequent motivation and interest.

Encouraging students to initiate activities and make task choices is an important strategy that may foster their commitment, positive attitudes, intellectual and moral growth, and a mastery orientation. When high school students receive the opportunity to choose tasks, they tend to select those that are personally challenging, rather than too easy or too hard. In turn, their chances of getting satisfaction for developing skills and knowledge are increased (Nicholls, 1989).

Continued motivation and increased sense of self-reliance are other characteristics of students placed in classroom settings that promote making decisions experiences (Maehr, 1983, 1984). Making students understand the purpose and meaningfulness of the learning process increases their participation in the negotiation and organization of the classroom setting. Sharing classroom control can influence the students' commitment to the learning process, although it is important to acknowledge that the primary authority or control within the classroom clearly rests to the teacher. Control, authority, and firmness are necessary in the classroom; however, this does not mean that teachers must act with totalitarianism and towards the students' needs and interests (Raffini, 1993).

Therefore, involving students in decision making, self-managing, self-monitoring skills; developing leadership roles; setting and enforcing rules; and enforcing logical consequences rather than punishment, encourages motivation toward mastery goals. Further, students must be held accountable for their behavior
(Ames, 1992a, 1992b; Epstein, 1988, 1989; Raffini, 1993). By encouraging a dynamic interaction among teacher and students, children feel that they have some control over the learning process, and are empowered to take some responsibility about their learning.

Recognition: recognition structure is a formal or informal use of rewards, incentives, and praise used in the classroom to recognize the students' efforts and accomplishments (Ames, 1992a; Epstein, 1988, 1989). Epstein suggested that, by having the history of previous accomplishments and skills, and the actual outcomes of each student, teachers could design an equity structure of rewards that acknowledge effort and achievement. However, it must be carefully planned to avoid social comparison. When recognition is private, the child's sense of pride and satisfaction is derived from doing his/her best and not by outperforming peers (Ames, 1992a).

Maintaining or boosting the students' motivation to learn can be achieved by (1) recognizing and rewarding their individual progress and improvements; (2) creating opportunity for recognition; (3) giving recognition and rewards privately, so that their values are not derived at the expense of others; and (4) focusing on the children's self-worth (Ames, 1992a; Epstein, 1988, 1989).

Grouping: the grouping structure determines whether, how and why students, who are similar or different in particular characteristics (e.g., gender, race, ability, goals, or interests), are brought together or kept apart for instruction, play, or other activities. Schools guide the students' interactions in peers and friendship groups, and, in doing so, directly influence the motivation to learn (Epstein, 1988, 1989). Teachers can enhance students' motivation toward a mastery orientation when providing flexible and heterogeneous grouping arrangements, and opportunities (Ames, 1992a; Epstein, 1988). Gano-Overway and Ewing (2004) suggested that students peer working creates a climate that encourages them to share effective practice strategies, or develop new strategies as they help each other to solve problems.

It is also important to recognize the major challenge for a teacher to establish a mastery climate, is to build up an environment where the individual differences are accepted, and all children develop 
belonging feeling. Belonging to a social group is fostered by cooperative work, peer interaction, encouragement of individual initiative, and peer and teacher support.

Evaluation: the evaluation structure is concerned by proving an effective evaluation system that leads the student to acknowledge his/her effort, abilities, and improvement. The main principles are to avoid social comparison and empower private evaluations. Nicholls (1989) affirms that public evaluation arouses concerns about the adequacy of one's ability, and consequently increases the tendency to consider ability as capacity. On the other hand, when the instructional emphasis is based on learning, understanding, solving problems, and/or performing a specific action, the conception of ability as capacity becomes irrelevant. In other words, when the evaluation is based on performance improvements, understanding profits, and/or efficiency in task performance, ability is not the same as capacity. Thus, peers social comparison can hinder motivation. In the very act of accomplishing, understanding, or learning, we achieve a sense of competence. That is, the activity will be experienced as an end itself, and it will be more intrinsically satisfying.

According to Ames (1992b), when correctness, absence of errors, and normative success are emphasized, a performance orientation is observed. Ames found that children exhibited doubts about their ability, avoided taking risks, used less effective learning strategies, and showed a negative affect toward themselves when receiving unfavorable social comparisons in the classroom. Also, social comparisons seem to (1) affect the children's interest in challenging tasks and the use of learning strategies; (2) threat the children's sense of control; (3) result in low intrinsic involvement in tasks and less interest in future learning (Maehr, 1984); (4) lower intrinsic interest in tasks (Csikszentmihalyi, 1975); (5) attenuate behavioral preference for challenging tasks and increased anxiety (Harter, 1978); (6) decrease interest in learning due to the overwhelming information about peers performance (Levine, 1983); (7) interfere in the judgment of competence (Nicholls, 1989); (8) foster social competition, leading the student to adopt an extrinsic orientation (Harter, Whitesell \& Kowalski, 1992; Maehr, 1983); (9) lead students to discontinue working independently to master the task and to seek new challenges and opportunities (Maehr, 1984).

Therefore, evaluative, interpersonal competitive conditions, and those that induce public self-awareness increase the extent to which competence is evaluated according to the conception that considers ability as capacity (Nicholls, 1989). Consequently, the intrinsic involvement in the process of performing tasks declines occur. This extrinsic orientation encourages the students to become especially sensitive about their ability. Although the author suggests that it may not affect the most competent student, it may have a definite negative effect on individuals with low perceptions of competence. In addition, students are more likely to demonstrate extrinsic motivation when extrinsic rewards are prominent features of the classroom instruction (Maehr, 1984).

On the other hand, if mastery environment is the purpose, the focus is the comparison of the present and previous levels, which supports the interest in learning. The absence of social comparison seems to greater feelings of competence associated with high effort (Jagacinski \& Nicholls, 1987). When students perceive that effort is valued, mistakes are part of learning, and the focus is on self-improvement, they exhibit the use of effective learning and problem-solving strategies; material and adaptive motivational patterns better recall; and focus on mastery rather than on performance goals (Ames, 1992b).

Students' wise knowledge about their own effort, abilities, and improvement can be achieved throughout an effective evaluation structure. This evaluation should contain challenging, yet attainable standards; fair and clear procedures for monitoring progress, and feedback. Strategies that foster students' mastery orientation include (1) individual progress criteria, improvement, and mastery; (2) feedback; (3) children self-evaluation, making the evaluation private and meaningful; and (4) reasonable opportunities for students to experience success from their efforts (Epstein, 1988). In other words, evaluation geared toward individual progress and mastery.

Time: time structure refers to the workload adequacy, the pace of instruction, and learning tasks time (Ames, 1992b). The teacher should incorporate flexible schedules for students providing them enough 
instructional time and assignments. In this way, the students' pace of learning is respected (Ames, 1992a; Epstein, 1989). Strategies such as providing opportunities and time for improvement, helping students to establish work, and practice schedules foster student motivation.

In conclusion, the TARGET structure provides a conceptual framework in which mastery climate may be implemented into the classroom. Mastery climate is considered relevant when value is placed on the process of learning through the emphasis on meaningful learning, self-referenced standards, and opportunities for self-directed learning (Ames, 1992b). The classroom, like other learning environments, has a fundamental influence on shaping patterns of motivation. Researches using the TARGET structure in schools have demonstrated that students' mastery experiences in these settings were critical for: (1) developing positive attitudes toward learning (Ames, 1992b; Morgan \& Carpenter, 2002); (2) fostering autonomy (Wallhead \& Ntoumanis, 2004), intrinsic motivation (Valentini, 1997), perceived ability (Cecchini-Estrada, González, Carmona, Arruza, Escarti \& Balagué, 2001), and perceived competence (Weigand, Burton, 2001); (3) increasing classroom achievements (Ames, 1992b), satisfaction (Weigand \& Burton, 2002), and enjoyment (Morgan \& Carpenter, 2002; Wallhead \& Ntoumanis, 2004); (4) demonstrating effort in physical education classes (Cecchini-Estrada et al., 2001; Wallhead \& Ntoumanis, 2004); and (5) enhancing preference for challenging tasks, as well as continuing to strive for improvements (Morgan \&Carpenter, 2002).

\section{Mastery Climate and TARGET Motor Skill Interventions}

Although the mastery climate studies have shown relevant results for the classroom interventions, there are few researchers, focused on the influence of mastery climate motor skill intervention about the psychological and behavioral responses of young children, especially for those who have demonstrated difficulties on peer tasks. Children who demonstrate delays in motor skill development may be susceptible to dropout or not engage in movement and sport settings (Dunn, 2000; Dweck, 1984, 1986). As Ames (1992a) suggested, "there are some children who have few skills, are often physically awkward or cognitively unprepared for learning, lack self-confidence, and are fearful about making a commitment" (p.170).

Therefore, the concern of children who demonstrate developmental motor delays goes beyond the actual delay itself and may also include concerns about motivation and attitudes toward physical activities (Harter, 1981; Harter, Marold, Whitesell \& Cobbs, 1996; Nicholls, 1984; Roberts, 1992). This combined effect may deprive children of participating and engaging in future physical activities and suggests that they need to be in touch with appropriate learning experiences to promote motor skill development and learning.

Considering the importance of motor skill intervention, several studies have shown significant changes in motor development as a result of being exposed to a direct instruction of motor skill intervention (Connor-Kuntz\& Dummer, 1996; Goodway \& Branta, 2003; Hamilton, Goodway \& Haubenstricker, 1999; Kelly, Dagger \& Walkley, 1989). However, as the recent research previously has shown, more traditional, direct instructional environments may not be the most advantageous for promoting development, learning, and motivation (Christodoulidis et al., 2001; Dunn, 2000; Newsham, 1989; Ntoumanis \& Biddle, 1999a, 1999b; Papaioannou, 1995, 1997, 1998; Papaioannou et al., 1999; Theeboom, De Knop \& Weiss, 1995; Treasure, 1997; Treasure \& Roberts, 2001; Valentini, 1997, 2002a, 20002b; Valentini \& Rudisill, 2004a, 2004b).

The motor skills research has revealed that the adoption of a mastery climate intervention leads children to experience improvements in motor skill development, and significant increases in feelings of competence (Goodway, Rudisill \& Valentini, 2002; Newsham, 1989; Theeboom et al., 1995; Valentini, 2002a, 2002b; Valentini \& Rudisill, 2004a, 2004b). Specifically, the studies conducted by Valentini (2002a, 2002b) and Valentini and Rudisill (2004a, 2004b) adopting the TARGET structure have showed that children with motor delays, who had a mastery motor skill intervention, demonstrated greater changes in locomotor and object control skills than children in traditional and control groups. Furthermore, considering psychological responses, children involved in mastery intervention showed significant changes in perceptions of 
competence (Valentini, 1997, 2002a; Valentini \& Rudisill, 2004a) and intrinsic orientation (Valentini, 1997).

Besides providing additional support for the mastery climate approach, the results from Valentini and Rudisill's (2004a) study revealed that children who have participated in the mastery climate intervention were able to maintain the benefits of the intervention over a six-month period. The author suggested that the increases in motor skill competence and perceptions of physical competence may have influenced future motivation to engage in behavior that resulted in the participants maintaining their levels of performance over time. This observed pattern of change is congruent with Harter's (1978) competence motivation theory, which suggests that children's self capabilities judgments influence their motivation and performance in that context. The more competent the child perceives himself or herself, the more positive his or her affective reactions are, and, the most comfortable the child feels to manifest intrinsically motivated behaviors (Harter et al., 1992). Consequently, intrinsically motivated children are to consistently engage in learning activities.

These findings strongly support the mastery climates application in movement and physical education settings in order to attend children with developmental delays. Positive environmental provides an important source of competence information that allows children to enjoy movement experiences as well as they feel better about their competence (Weiss, 1991, 1995). As Brophy (1983) stated, if educators are serious about the need for enhancing students' motivation and engagement in learning, they need to focus on classroom environment, and examine how the classroom can be structured to optimize motivation. Implementing mastery climates seems to be an approach to accomplish higher motivation and achievement.

\section{Theoretical and practical issues related to children's motivation}

Contemporary literature defines important parameters in the study of human motivation, especially in the study of children's motivation. The knowledge of how and why children demonstrate some motivational patterns in achievement settings is extensive. However, translating this theory into practice is still a challenge to educators. Studies incorporating the TARGET structure and its application to educational settings are turning points for practitioners. These instructional strategies seem to be effective for helping students to become actively involved to their own learning and engagement in achievement strategies to facilitate their skill development (Gano-Overway \& Ewing, 2004), consequently enhancing achievement and perceptions of competence.

Furthermore, it is time to relate theoretical approaches to naturalistic settings in order to understand children's motivation and achievements, and to create and implement appropriate environment for learning. There is also a considerable amount of promising evidence (Valentini, 2002a; Valentini \& Rusisill, 2004b) that supports the implementation of a mastery climate intervention for children with disability who are in inclusive environments. Regardless to the initial level of motor ability, a mastery climate intervention seems to accommodate and challenge all learners. It is also important to acknowledge that other research findings support that mastery climates create equitable learning opportunities for participants (Duda, Olson \& Templin, 1991; Papaioannou, 1995, 1998).

There is much to be gained, both theoretically and practically, from pursuing a methodology for implementing a mastery climate in learning environments. In pursuing this line of research, a guide to implement intervention programs would be a great benefit to students, researchers, and practitioners. This approach enables the teacher to meet the needs of children with diverse skill levels and experiences, and teaches children to be autonomous in the learning process.

Future research also should focus on developing measures for goal orientation in young children, since they are also exposed to helpless patterns of motivation. However, the lack of instruments designed to assess young children's perceptions of climates in learning environments is a clear obstacle to investigate all the psychological dimensions of children's achievement motivation. Furthermore, as the majority of the investigations reported in the literature are cross-sectional, there is very little evidence on the long-term effects of this approach (Christodoulidis 
et al., 2001; Gano-Overway \& Ewing, 2004; Valentini \& Rudisill, 2004). It is needy to develop longitudinal studies to investigate the effects of mastery climate intervention on student motivational responses during his/her growth, as student's goal orientation may change through the school time and the goals adopted are influenced by their socialization experiences (Gano-Overway \& Ewing, 2004). Cross-sectional designs provide no strong evidence about how the goal orientation pattern has been shaped by the environment.

The direction of future research in this area, as discussed by Schunk (1999) and Elliot and McGregor (1999), and reemphasized by Xiang et al. (2004), should include a multiple theoretical framework - integrated perspective - to examine the student motivational process. Achievement motivation is a complex process affected by numerous variables. Efforts to clarify these issues will provide valuable knowledge to researchers and practitioners in the understanding of motivation and learning.

\section{References}

Ames, C. (1984a). Achievement attributions and selfinstructions under competitive and individualistic goal structures. Journal of Educational Psychology, 76, 478-487.

Ames, C. (1984b). Competitive, cooperative, and individualistic goal structure: a cognitive-motivational analysis. In R. Ames \& C. Ames (Eds.), Research on Motivation in Education (Vol. 1, pp.177-208). New York: Academic Press.

Ames, C. (1987). The enhancement of student motivation. In D. Kleiber \& M. Maehr (Eds.), Advances in motivation and achievement (pp.123-148). Greenwich, CT: JAI Press.

Ames, C. (1992a). Achievement goals, motivational climate, and motivational processes. In: G. C. Roberts (Ed.), Motivation in sport and exercise (pp.161-176). Champaign, IL: Human Kinetics Publishers.

Ames, C. (1992b). Classroom: goals, structures, and student motivation. Journal of Educational Psychology, 84, 409-414.

Ames, C., \& Archer, J. (1988). Achievement of goals in the classroom: Students' learning strategies and motivation process. Journal of Educational Psychology, 80, 260-267.

Biddle, S. J. H., Wang, J. C. K. J., Kavussanu, M., \& Spray, C. M. (2001). Correlates of achievement goal orientation in physical activity: A systematic review of research. European Journal of Sport Science, 3 (5), 433-444.

Brookhart, S. M., \& Durkin, D.T. (2003). Classroom assessment, student motivation, and achievement in high school social studies classes. Applied Measurement in Education, 16 (1), 27-54.

Brophy, J. (1983). Conceptualizing students' motivation. Educational Psychologist, 18, 200-215.

Burhands, K. K., \& Dweck, C. S. (1995). Helplessness in early childhood: the role of contingent worth. Child Development, 66, 1719-1738.

Butler, R. (1987). Task-involving and ego-involving properties of evaluations: The effects of different feedback conditions on motivational perceptions, interest and performance. Journal of Educational Psychology, 79, 474-482.

Cecchini-Estrada, J. A., González, C., Carmona, A. M., Arruza, J., Escarti, A., \& Balagué, G. (2001). The influence of the teacher of physical education on intrinsic motivation, self-confidence, anxiety, and pre- and post-competition mood states. European Journal of Sport Science, 1 (4), 168-183.

Christodoulidis, T., Papaioannou, A., \& Digelidis, N. (2001). Motivational climate and attitudes towards exercise in Greek senior high school: a year-long intervention. European Journal of Sport Science, 1 (4), 144-152.

Connor-Kuntz, F., \& Dummer, G. (1996). Teaching across the curriculum: language enriched physical education for preschool children. Adapted Physical Activity Quarterly, 13, 302-315.

Corno, L., \& Rohrkemper, M. (1985). The intrinsic motivation to learn in the classroom. In C. Ames \& R. Ames (Eds.), Research on motivation in education (Vol. 2, pp.53-90). New York: Academic Press.

Covington, M. V. (1984). The motive for self-worth. In R. Ames \& C. Ames (Eds.), Research on motivation in education (Vol.1, pp.77-113). New York: Academic Press.

Csikszentmihalyi, M. (1975). Beyond boredom and anxiety. San Francisco: Jossey-Bass.

Duda, J. L. (1992). Motivation in sport settings: A goal perspective approach. In G. C. Roberts (Ed.), Motivation in sport and exercise (pp.57-91). Illinois: Human Kinetics Publishers.

Duda, J. L., Olson, L. K., \& Templin, T. J. (1991). The relationship of task and ego orientation to sportsmanship attitudes and the perceived legitimacy of injurious acts. Research Quarterly for Exercise and Sport, 62, 79-87.

Dunn, J. C. (2000). Goal orientation, perceptions of the motivational climate, and perceived competence of children with movement difficulties. Adapted Physical Activity Quarterly, 17, 1-19.

Dweck, C. S. (1984). Intrinsic motivation, perceived control, and self-evaluation maintenance: An achievement goal analysis. In R. Ames \& C. Ames (Eds.), Research on motivation in education (Vol. 3, pp.289-303). New York: Academic Press.

Dweck, C. S. (1986). Motivational processes affecting learning. American Psychologist, 41, 1040-1048.

Dweck, C. S., \& Leggett, E. L. (1988). A social-cognitive approach to motivation and personality. Psychological Review, 95, 256-273. 
Elliott, E. S., \& Dweck, C. S. (1988). Goals: An approach to motivation and achievement. Journal of Personality and Social Psychology, 54, 5-12.

Elliot, A. J., \& McGregor, H. A. (1999). Test anxiety and the hierarchical model of approach and avoidance achievement motivation. Journal of Personality and Social Psychology, 76, 628-644.

Epstein, J. (1988). Effective schools or effective students? Dealing with diversity. In R. Hawkins \& B. MacRae (Eds.), Policies for America's public schools (pp.89-126). Norwood, NJ: Ablex.

Epstein, J. (1989). Family structure and students motivation: a development perspective. In C. Ames \& R. Ames (Eds.), Research on motivation in education (Vol. 3, pp.259-295). New York: Academic Press.

Gano-Overway, L. A., \& Ewing, M. E. (2004). A longitudinal perspective of the relationship between perceived motivational climate, goal orientations, and strategy use. Research Quarterly for Exercise and Sport, 75 (3), 315-326.

Goodway, J. D., \& Branta, C. F. (2003). Influence of a motor skill intervention on fundamental motor skill development of disadvantaged preschool children. Research Quarterly for Exercise and Sport, 74 (1), 36-46.

Goodway, J. D., Rudisill, M. E., \& Valentini, N. C. (2002). The influence of instruction on the development of catching in young children. In J. E. Clark \& J. Humphrey (Eds.), Motor development: research and reviews (Vol. 2). Reston: NASPE Publication.

Hamilton, M., Goodway, J., \& Haubenstricker, J. (1999). Parentassisted instruction in a motor skill program for at-risk preschool children. Adapted Physical Activity Quarterly, 16 (4), 415-426

Harter, S. (1978). Effectance motivation reconsidered: toward a developmental model. Human Development, 21, 34-64.

Harter, S. (1981). A new self-report scale of intrinsic versus extrinsic orientation in the classroom: Motivational and informational components. Developmental Psychology, 17, 300-312.

Harter, S., Whitesell, N. R., \& Kowalski, P. (1992). Individual differences in the effects of educational transitions on young adolescent's perceptions of competence and motivational orientation. American Educational Research Journal, 29, 777-807.

Harter, S., Marold, D., Whitesell, R., \& Cobbs, G. (1996). A Model of the effects of perceived parent and peer support on adolescent false self behavior. Child Development, 67, 360-374.

Jagacinski, C. M., \& Nicholls, J. G. (1987). Competence and affect in task and ego involvement: the impact of social comparison information. Journal of Educational Psychology, 79, 107-114.

Kelly, L. E., Dagger, J., \& Walkley, J. (1989). The effects of assessment-based physical education program on motor skill development in preschool children. Education and Treatment of Children, 12 (2), 152-164.
Lepper, M. R., \& Hodell, M. (1989). Intrinsic motivation in the classroom. In R. Ames \& C. Ames (Eds). Research on motivation in education (Vol. 3, pp.73-105). New-York: Academic Press.

Levine, J. (1983). Social comparison and education. In J. Levine \& M.Wang (Eds.), Teachers and students perceptions: implications for learning (pp.111-134). Hillsdale, NJ: Erlbaum.

Maehr, M. L. (1983). On doing well on science. Why Johnny no longer excels; why Sarah never did. In S. G. Paris, G. M. Olson, H. W. Stevenson (Eds.), Learning and motivation in the classroom (pp.179-210). Hillsdale, NJ: Lawrence Erlbaum and Associates.

Maehr, M. L. (1984). Meaning and motivation: toward a theory of personal investment. In R. Ames \& C. Ames (Eds.), Research on motivation in education (Vol. 1, pp.115-144). New York: Academic Press.

Maehr, M. L., \& Midgley, C. (1991). Enhancing student motivation: a school wide approach. Educational Psychologist, 26, 399-427.

Martin, E. H. (2001). The effectiveness of a mastery motivational climate motor skill intervention in a naturalistic physical education setting. Unpublished doctoral dissertation, Auburn University, Auburn, Alabama.

Meece, J. L., Blumenfeld, P. C., \& Hoyle, R. H. (1988). Students' goal orientations and cognitive engagement in classroom activities. Journal of Educational Psychology, 4, 514-523.

Meece, J. L., \& Holt, K. (1993). A pattern analysis of students' achievement goals. Journal of Educational Psychology, 4, 582-590.

Miller, A. (1986). Performance impairment after failure: Mechanism and sex differences. Journal of Educational Psychology, 78, 486-491.

Morgan, K., \& Carpenter, P. (2002). Effects of manipulating the motivational climate in physical education lessons. European Physical Education Review, 8 (3), 207-229.

Newsham, S. (1989). The effects of a task-oriented physical education program on the self-perception of third, fourth, and fifth grade students. Unpublished doctoral dissertation, University of Southern California, Los Angeles, California.

Nicholls, J. G. (1984). Conceptions of ability and achievement motivation. In R. Ames \& C. Ames (Eds.), Research on motivation in education (Vol. 1, pp.39-73). New York: Academic Press.

Nicholls, J. G. (1989). The competitive ethos and democratic education. Cambridge, MA: Harvard University Press.

Nicholls, J. G. (1992a). The general and the specific in the development and expression of achievement motivation. In G. C. Roberts (Ed.), Motivation in sport and exercise (pp.31-56). Champaign, IL: Human Kinetics Publishers.

Nicholls, J. G. (1992b). Students as educational theorists. In D. H. Schunk \& J. L. Meece (Eds.), Students perceptions in the classroom. Hillsdale, NJ: Lawrence Erlbaum and Associates. 
Nichols, W. D., Jones, J. P., \& Hancock, D. R. (2003). Teachers' influence on goal orientation: Exploring the relationship between eighth graders' goal orientation, their emotional development, their perception of learning, and their teachers' instructional strategies. Reading Psychology, 24 (1), 57-85.

Ntoumanis, N., \& Biddle, S. J. H. (1999a). Affect and achievement goals in physical education: A meta analysis. Scandinavian Journal of Medicine and Science in Sports, 9, 315-332.

Ntoumanis, N., \& Biddle, S. J. H. (1999b). A review of motivational climate in physical activity. Journal of Sports Sciences, 17, 643-665.

Papaioannou, A. (1995). Differential perceptual and motivational patterns when different goals are adopted. Journal of Sport \& Exercise Psychology, 17, 18-34.

Papaioannou, A. (1997). Perceptions of motivational climate, perceived competence, and motivation of students of varying age and sport experience. Perceptual and Motor Skills, 85 (2), 419-431.

Papaioannou, A. (1998). Students' perceptions of the physical education class environment for boys and girls and the perceived motivational climate. Research Quarterly for Exercise and Sport, 69 (3), 267-275.

Papaioannou, A., \& Kouli, O. (1999). The effect of task structure, perceived motivational climate, and goal orientations on student's task involvement and anxiety. Journal of Applied Sport Psychology, 11, 51-71.

Raffini, J. P. (1993). Winners without losers: Structure and strategies for increasing student motivation to learn. Boston, MA: Allyn and Bacon.

Roberts, G. C. (1992). Motivation in sport and exercise: Conceptual constraints and convergence. In G. C. Roberts (Ed.), Motivation in sport and exercise (pp.3-32). Champaign, IL: Human Kinetics.

Rudisill, M. E. (1989). The influence of various achievement goal orientations on perceived competence and the attributional process. Journal of Human Movement Studies, $16,55-73$.

Rudisill, M. E. (1991). The influence of various achievement goal orientations on children's perceived competence, expectations, persistence and performance for three motor tasks. Journal of Human Movement Studies, 18, 44-61.

Rudisill, M. E., Mahar, M. T., \& Meaney, K. S. (1993). The relationship between children's perceived and actual motor competence. Perceptual and Motor Skills, 76, 895-906.

Schunk, D. H. (1999). Introduction to the special section on motivation and efficacy. Journal of Educational Psychology, 82, 3-6.

Seifriz, J. J., Duda, J. L., \& Chi, L. (1992). The relationship of perceived motivational climate to intrinsic motivation and beliefs about success in basketball. Journal of Sport \& Exercise Psychology, 14, 375-391.

Smiley, P. A., \& Dweck, C. S. (1994). Individual differences in achievement goals among young children. Child Development, 65, 1723-1743.
Standage, M., Duda, J., \& Ntoumanis, N. (2003). A model of contextual motivation in physical education: using constructs from self-determination and achievement goals theories to predict physical activity intentions. Journal of Educational Psychology, 95 (1), 97-110.

Stipek, D. J., \& Kowalski, P. S. (1989). Learned helplessness in task-oriented versus performance-oriented testing conditions. Journal of Educational Psychology, 81, 384-391.

Stornes, T., \& Ommundsen, Y. (2004). Achievement goal, motivational climate and sporpersonship: a study of young handball players. Scandinavian Journal of Educational Research, 48 (2), 205-221.

Theeboom, M., Knop, P. D., \& Weiss, M. R. (1995). Motivational climate, psychological responses, and motor skill development in children's sport: a field-based intervention study. Journal of Sport Psychology, 17, 294-311.

Treasure, D. C. (1997). Perceptions of the motivational climate and elementary school children's cognitive and affective response. Journal of Sport \& Exercise Psychology, $19,278-290$

Treasure, D. C., \& Roberts, G. C. (2001). Student's perceptions of the motivational climate, achievement beliefs and satisfaction in physical education. Research Quarterly for Exercise and Sport, 72, 165-175.

Valentini, N. C. (1997). The influence of two motor skill interventions on the motor skill performance, perceived physical competence, and intrinsic motivation of kindergarten children. Unpublished master's thesis, Auburn University, Auburn, Alabama.

Valentini, N. C. (2002a). A influência de uma intervenção motora com contexto de motivação para a maestria no desenvolvimento motor de crianças portadoras ou não de necessidades especiais: uma perspectiva inclusiva. In Anais do Seminário de Comportamento Motor, Gramado, 3.

Valentini, N. C. (2002b). A influência de uma intervenção motora no desempenho motor e na percepção de competência de crianças com atrasos motores. Revista Paulista de Educação Física, 16 (1), 61-75.

Valentini, N. C., \& Rudisill, M. E. (2004a). Motivational climate, motor-skill development and perceived competence: Two studies of developmental delayed kindergarten children. Journal of Teaching in Physical Education, 23, 216-234.

Valentini, N. C., \& Rudisill, M. E. (2004b). An inclusive mastery climate intervention and the motor development of children with and without disabilities. Adapted Physical Activity Quarterly, 21, 330-347.

Valentini, N. C., Rudisill, M. E., \& Goodway, J. D. (1999a). Incorporating a mastery climate into elementary physical education: It's developmentally appropriate. Journal of Physical Education, Recreation, and Dance, 70, 28-32.

Valentini N. C., Rudisill, M. E., \& Goodway, J. D. (1999b). Mastery climate: Children in charge of their own learning. Teaching Elementary Physical Education, 10, 6-10. 
Wallhead, T. L., \& Ntoumanis, N. (2004). Effects of a sport education intervention on students' motivational responses in physical education. Journal of Teaching in Physical Education, 23, 4-18.

Walling, M. D., \& Duda, J. L. (1995). Goals and their associations with beliefs about success in and perceptions of the purposes of physical education. Journal of Teaching in Physical Education, 14, 140-156.

Walling, M., Duda, J., \& Chi, L. (1993). Perceived motivational climate in sport questionnaire: Construct and predictive validity. Journal of Sport \& Exercise Psychology, 15, 172-183.

Weigand, D. A., \& Burton, S. (2002). Manipulating achievement motivation in physical education by manipulating the motivational climate. Journal of Sport Science, 2 (11), 305-328.

Weiss, M. R. (1991). Psychological skill development in children. The Sport Psychologist, 5, 335-354.
Weiss, M. R. (1995). Children in sport: an educational model. In S. M. Murphy (Ed.), Sport psychology interventions (pp.36-69). Champaign, IL: Human Kinetics.

Wolters, C. A. (2004). Advancing achievement goal theory: using goal structures and goal orientations to predict students' motivation, cognition and achievement. Journal of Educational Psychology, 96 (2), 236-250.

Xiang, P., Lee, A., \& Bennett, S. J. (2002). Achievement goal, perceived motivational climate, and students' self-reported mastery behaviors. Research Quarterly for Exercise and Sport, 73 (1), 58-68.

Xiang, P., McBride, R., \& Guan, J. (2004). Children's motivation in elementary physical education: a longitudinal study. Research Quarterly for Exercise and Sport, 75 (1), 71-81.

Submitted on: 16/11/2004

Final version resubmitted on: 25/4/2005

Approved on: 30/5/2005 
